\section{History and Perspectives on the Use of Disease Resistance Inducers in Horticultural Crops}

\author{
Andrea B. da Rocha ${ }^{\mathrm{l}}$ and \\ Ray Hammerschmidt ${ }^{2}$
}

ADDITIONAL INDEX WORDS. systemic acquired resistance, systemic induced resistance, integrated pest management

SumMARY. A major challenge facing horticultural crop production is the need to provide field and postharvest disease control measures that help maintain high quality plant products. Producers and consumers also expect high quality produce with minimal or no pesticide residues and competitive prices. The chemical management of disease is further complicated by the development of fungicide resistance in many important pathogens. Because of these concerns, an alternative or complementary approach is the use of disease resistance inducers that activate the natural defenses of the plant. Induced disease resistance in plants has been studied in many different pathosystems for nearly a century. Resistance to plant disease can be induced systemically by prior infection with pathogens, by certain nonpathogenic microbes that colonize the surface of roots and leaves, or by chemicals. The application of resistance inducers should protect plants through the induction of defenses that are effective against a broad spectrum of pathogens. Over the last few years, a number of materials that could potentially be used as inducers of resistance in horticultural crops have been identified. Some of these materials are already commercially available. Although induced resistance

${ }^{1}$ Departamento de Fitotecnia, Universidade do Estado de Santa Catarina-UDESC, Bairro Conta Dinheiro, CEP: 88520-000 Lages-SC, Brazil.

${ }^{2}$ Department of Plant Pathology, Michigan State University, East Lansing, MI 48824-1311.

Acknowledgment. The authors thank the Michigan Agricultural Experiment Station for support of this work. is known to provide a broad spectrum of disease suppression, it may not be a complete solution because variation in the efficacy of disease resistance induction has been observed. The variation in the response may be dependent on the plant species and even cultivars, as well as variability in the spectrum of pathogens that resistance can be induced against. Induction of resistance depends on the activation of biochemical processes that are triggered in the plant, and therefore a lag time between treatment and expression of resistance occurs. This lag effect may limit the practical application of disease resistance inducers. Since the efficacy of the inducers also depends on the part of the plant that was treated, the product delivery (i.e., how the inducers would be applied in order to optimize their action) is another factor to be considered. Some studies have shown that there may be side effects on growth or yield characteristics when certain inducers are used. Understanding the biochemical interactions occurring between plants, pathogens and the inducers will provide information that may be useful for the optimization of this new approach on disease control. Approaches to integrate induced resistance with other management practices need to be investigated as a means to aid the development of sustainable disease management programs that are effective as well as economically and environmentally sound.

A lthough there are many potential pathogens that come into contact with plants, the end result of these interactions is usually resistance. Hammond-Kosack and Jones (1996) suggest three reasons for this ability to resist infections. First, the plant species is not a host for the pathogen, and thus non-host resistance is expressed; second, the plant has preformed structural or chemical barriers that prevent infection; and, third, recognition of the pathogen by the plant results in the activation of host defenses that stop pathogen ingress into the tissue. The third form of resistance includes defenses that are expressed locally as well as the systemic expression of resistance to subsequent infections.

Disease management in horticultural crops relies on the use of commercially acceptable disease resistant cultivars, use of cultural practices that reduce field infections, and chemicals 
that protect the plants against infection. However, loss of fungicide efficacy because of resistance (e.g., Washington et al., 1992) and environmental and public concerns about the use of chemical disease management (Jacobsen and Backman, 1993; Oka et al., 2000) add to the challenges facing disease management in the future.

Postharvest disease control is important for maintaining product quality because many crops are often stored or shipped to locations at some distance from where they are harvested. Synthetic fungicides are currently a primary means used for controlling postharvest diseases (Barkai-Golan, 2001). However, the long-term use of fungicides is threatened because of development of resistance by postharvest pathogens to some fungicides and the withdrawal of a number of key fungicides in response to health and environmental concerns over pesticide contamination. Thus, the search for alternative technologies for postharvest disease control in horticultural crops has been stimulated (Barkai-Golan, 2001; Terry and Joyce, 2004).

The issues raised above have promoted the use of integrated pest management (IPM) practices for managing diseases of horticultural crops (Terry and Joyce, 2000). Because induced resistance is broad spectrum, uses natural defense mechanisms, and has been demonstrated to be effective in a number of crop species (Jensen et al., 1998; Sticher et al., 1997; Terry and Joyce, 2000) this form of disease management is potentially an integral part of IPM practices.

In this paper, we present a brief description of how the concept of induced resistance was developed and the main mechanisms involved in this phenomenon. We will describe types of products and experimental materials that are currently described as disease resistance inducers. Finally, we will discuss some characteristics of induced resistance that should be considered when applying resistance inducing materials to horticultural crops.

\section{History of induced resistance}

The resistance of plants to pathogens and herbivores is based on both constitutive barriers and induced defenses. Constitutive barriers can be chemical or structural and act as a passive form of defense (Hammerschmidt and Nicholson, 1999). Induced de- fenses are those that are activated after infection and can be either localized at the site of attack (Hammerschmidt and Nicholson, 1999) or can be expressed systemically throughout the plant (Sticher et al., 1997).

The ability of plants to express induced resistance to pathogens has been known for over a century and the topic was first reviewed by Chester (1933). These early observations emphasized the ability of plants to become resistant to subsequent inoculations after an initial infection occurred.

Induced resistance is also often referred to as "acquired resistance," a term first used by Ross (1961) who showed that inoculation of one lower leaf of a tobacco (Nicotiana tabacum) cultivar that was hypersensitively resistant to tobacco mosaic virus (TMV) increased the resistance of the upper leaves on the same plant to subsequent infection with TMV. The resistance in this upper leaf was expressed as a reduction in the number and size of local lesions formed. Later work showed that the inducer inoculation not only triggered resistance to TMV, but also to unrelated fungal and bacterial pathogens (reviewed in Hammerschmidt and Dann, 1997; Sticher et al., 1997).

Later, Kuc' and his coworkers have extensively described induced resistance in bean (Phaseolus vulgaris) (Elliston et al., 1971) and cucumber (Cucumissativus) (Hammerschmidt et al., 1976) and documented the broad spectrum of induced resistance. These studies made it clear that induced resistance was expressed independently of the type of pathogen used for resistance induction (Madamanchi and $\mathrm{Kuc}^{\prime}, 1991$ ). The pioneering studies of Ross, Kuc', and others (Kuc', 1982; Ross, 1961) clearly showed that a localized infection with a necrotic lesion causing pathogen leads to resistance against a subsequent infection to a broad spectrum of pathogens. They showed that resistance is expressed not only locally at the site of primary inoculation but also systemically (i.e., in tissues remote from the initial treatment). This form of induced resistance is called systemic acquired resistance (SAR) and is expressed throughout the plant (Hammerschmidt, 1999). SAR has specific characteristics such as a need for a necrotic lesion producing pathogen as the inducing agent, systemic expression of pathogen-related (PR) protein genes, and involvement of salicylic acid as part of the signaling process (Hammerschmidt, 1999).

Another form of induced resistance, known as induced systemic resistance (ISR) is activated by growth promoting rhizobacteria (PGPR) that colonize the rhizosphere (Alström, 1991; Pieterse et al., 1996). Some PGPR, after application to the soil, become localized at the root surface and induce resistance in the leaves and stem. Unlike pathogens that induce SAR, PGPR protect plants systemically against various pathogens without causing any of their own symptoms (Liu et al., 1995a, 1995b; Pieterse et al., 1996; Van Peer et al., 1991). To date, induced resistance has been shown in more than 30 plant species of both dicotyledonous and monocotyledonous plants (Sticher et al., 1997).

\section{Mechanisms involved in induced resistance}

The identification of key regulatory pathways and genes involved in both the SAR and ISR forms of induced resistance and challenge with different types of pathogens has provided further evidence that these two types of induced resistance are different and may protect against different types of pathogens (Pieterse and Van Loon, 1999). In this section, some of these differences will be discussed.

SAR was initially characterized as a type of induced resistance that was induced in response to pathogens that cause a localized, necrotic lesion. This necrotic lesion can be a result of a successful infection or a hypersensitive reaction (HR) (Hammerschmidt, 1999). SAR has also been shown to be effective against a wide range of pathogens and is associated with the accumulation of $\mathrm{PR}$ proteins. SAR is also mediated by the salicylic acid (SA) pathway (Sticher et al., 1997). Because SAR can be induced by synthetic compounds that mimic salicylic acid and do not induce necrotic lesions [e.g., acibenzolar-S-methyl (Oostendorp et al., 2001)], a general way to define SAR is as a type of induced resistance that is broad spectrum, dependent on SA and associated with PR protein production.

ISR develops systemically in response to colonization of roots by certain rhizosphere bacteria, known as PGPR. This type of resistance shows host specificity in regard to eliciting 
resistance (Ton et al., 2001; Van Wees et al., 1997), and this suggests that specific recognition between protective bacteria and the plant is a prerequisite for the activation of the signaling cascade leading to ISR. In contrast to SAR, ISR is not associated with the expression of PR genes (Van Wees et al., 1997), is not mediated by the SA pathway. However, ISR is mediated by a jasmonate/ethylene pathway (Pieterse et al., 1998). In a study using various arabidopsis (Arabidopsis thaliana) mutants, Pieterse and collaborators showed that ISR follows a signaling pathway that requires responsiveness to ethylene and jasmonic acid (JA), and this results in the ability of the host to mount a defense response upon infection (Pieterse et al., 1998).

Although the signaling pathway and spectrum of pathogens protected against by SAR and ISR differ, both types of induced resistance require the NPRI gene. NPRl protein is required for regulation of $S A R$ responses downstream of SA perception and it is needed for the expression of resistance and PR protein genes (Ryals et al., 1997). Although ISR expression is not associated with $\mathrm{PR}$ proteins accumulation, NPRl is still necessary (Pieterse et al., 1998). Induced resistance, however, may utilize other regulatory genes. For example, it has been shown that SA-dependent resistance of arabidopsis to a viral pathogen is independent of NPRI (Kachroo et al., 2000). Although different signaling pathways are used for ISR and SAR, the two forms of resistance can be simultaneously activated in the same plant leading to enhanced resistance (Van Wees et al., 2000). These results indicate that several different defense signaling pathways may operate, may share the same components (Métraux et al., 2002), the two can simultaneously be activated and this may increase the utility of induced resistance to protect plants against a broad spectrum of pathogens (Métraux et al., 2002).

In the next section we will present a discussion about the possible uses of induced resistance in horticultural crops. We will describe the end result of plants treated with resistance inducers or activators as simply "induced resistance" because it is often not known if the resistance being induced is ISR, SAR or some other form of induced resistance that has not yet been characterized.

\section{Disease resistance inducers in horticultural crops}

The resistance-inducing agents can be biotic or abiotic in nature. Inoculation with non-pathogens or pathogens, inactivated pathogens, incompatible races of pathogens, saprophytes, PGPR or symbionts are examples of biotic resistance inducing agents. Examples of abiotic resistance inducers are naturally occurring metabolites, inorganic compounds or synthetic chemical compounds. Many agents have been claimed to induce resistance. However, some criteria need to be used to evaluate if a material protects plants via induced resistance. Sticher et al. (1997) noted that the inducer, if it is a chemical compound, cannot be antimicrobial nor can it be converted into an antimicrobial compound by the plant. Furthermore, the inducing agent must alter the plant response from compatibility to incompatibility (including the expression of plant defenses). Finally, the inducer must protect the plant against pathogens (Sticher et al., 1997).

Biotic Disease Resistance INDUCERs. There are many examples of biotic inducers. In this section we describe a few recent examples that are relevant to horticultural crops. Ramamoorthy et al. (2002) evaluated 20 isolates of fluorescent pseudomonad growth promoting rhizobacteria for their ability to control damping-off in tomato (Lycopersicon esculentum) and hot pepper (Capsicum annuиm). These bacteria were antagonistic to pathogenic Pythium species that cause damping off and they induced defenserelated enzymes of the phenylpropanoid pathway in the treated plants. The expression of these enzymes was suggested to contribute to enhanced resistance against invasion of pythium in tomato and hot pepper plants.

In another study with tomato, inoculation of green parts of the plants with Phytophthora cryptogea zoospores induced systemic resistance against the root invading vascular wilt pathogen Fusarium oxysporum f.sp. lycopersici under growth chamber conditions. The plants treated with P. cryptogea showed no disease symptoms during the $50 \mathrm{~d}$ following challenge with $F$. oxysporum f.sp. lycopersici, while the control plants were destroyed by wilt within about 40 d (Attitalla et al., 2001).

Resistance to Botrytis cinerea in the upper half of cold stored carrot (Daucus carota) roots can be induced by prior inoculation at one site on the lower half with the same pathogen or with Sclerotinia sclerotiorum (Mercier et al., 1993). Also, heat-killed conidia of $B$. cinerea have been reported to induce resistance to $B$. cinerea in carrot slices through enhanced suberization and localized phytoalexin accumulation (Garrod et al., 1982; Harding and Heale, 1981; Heale and Sharman, 1977).

Greenhouse crop production can be seriously impacted by soilborne pathogens that colonize sterilized potting mixtures and soils and subsequently cause losses on plants grown in these infested media (Jarvis, 1989). Working with compost prepared from pulp and paper mill residues, Pharand et al. (2002) demonstrated that this compost reduced symptoms of the disease caused by F. oxysporum f.sp. lycopersici in tomato plants and, through cytological analysis, demonstrated that the basis for this disease suppression was induced resistance. The authors also suggest that amendment of composts with specific antagonists such as Pythium oligandrum may be a valuable option for amplifying their beneficial properties in terms of tomato disease suppression in greenhouse.

Oligomers of chitosan (polyn-glucosamine), which are likely to be released from fungal cell walls by plant chitosanases, can protect tomato roots against F. oxysporum f.sp. radicislycopersici when applied to the seeds, roots, or to leaves (Benhamou and Theriault, 1992; Benhamou et al., 1994). In this example, the authors showed that ultrastructural changes such as cell necrosis and deposition of lignin-like and callose-like materials took place in pretreated and in $\mathrm{Fu}$ sarium-challenged roots (Benhamou and Theriault, 1992).

Spraying an extract of spinach (Spinacia oleracea) or rhubarb (Rheum rhabarbarum) leaves on the undersides of cucumber leaves induced systemic resistance against Colletotrichum lagenarium, the pathogen that causes anthracnose. Induced resistance was evident within $20-36 \mathrm{~h}$ after spraying with the extracts. Oxalic acid was identified as the active component of both extracts (Doubrava et al., 1988).

Polyunsaturated fatty acids such as arachidonic, linolenic, linoleic, and oleic acid induce resistance in potato 
(Solanum tuberosum) against $P$. infestans (Cohen et al., 1991). This effect is not accompanied by enhanced SA levels or by SAR-gene expression in the systemically protected parts of the plant. Arachidonic acid is naturally present in spores and mycelium of $P$. infestans and is released in the plant tissue after infection thus acting as a non-specific elicitor from this oomycete (Ricker and Bostock, 1992).

Natural products previously tested in horticultural crops and reported to be disease resistance inducers are summarized in Table 1.

Abiotic Disease RESISTANCE INDUCERS. A list of abiotic compounds that have been reported to induce re- sistance is shown in Table 2. Phosphate salts induced resistance in cucumber, lettuce (Lactuca sativa), and pepper (Capsicum annuum) (Irving and Kuc', 1990; Pajot et al., 2001; Reuveni et al., 1998). It was proposed that calcium sequestration at the site of application by phosphates generates an endogenous signal that triggers SAR (Gottstein and $\left.K^{\prime} c^{\prime}, 1989\right)$. In cucumber, supplying phosphate at concentrations of 5, 20 and $40 \mathrm{mg} \cdot \mathrm{L}^{-1}(\mathrm{ppm})$ through a hydroponic system was reported to induce resistance against powdery mildew. In the same study, foliar application of a $1 \%$ solution of mono-potassium phosphate protected the foliage against powdery mildew regardless the phosphorous concentration in the hydroponic solution. The authors noted that the protection was persistent up to $2 \mathrm{ld}$ after inoculation with Sphaerotheca fuliginea, and it significantly inhibited the sporulation of the fungus (Reuveni et al., 2000).

Phytogard [a crop-protection material that contains $\mathbf{5 8} \%$ potassium phosphonate $\left(\mathrm{K}_{2} \mathrm{HPO}_{3}\right)$ and $42 \%$ water (Bécot et al., 2000)] has been reported to induce resistance in lettuce plants (Pajot et al., 2001) and cauliflower (Brassica oleracea var. botrytis) (Bécot et al., 2000) to downy mildew (Peronospora parasitica). However, the active ingredient (potassium phosphonate) is also directly active against downy

Table 1. List of natural compounds claimed in the literature as disease resistance inducers in horticultural crops., $\mathrm{y}$

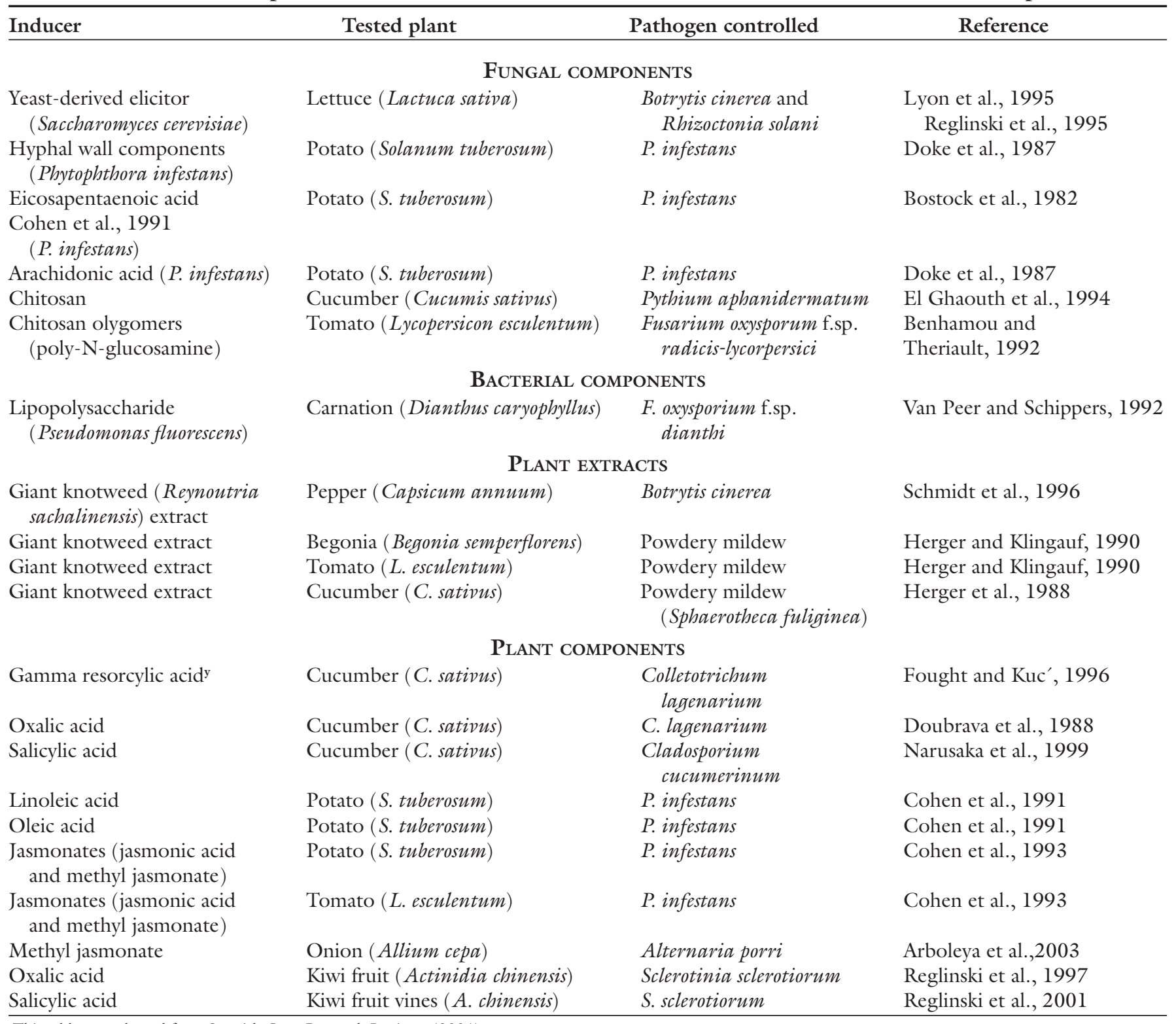

${ }^{2}$ This table was adapted from Scottish Crop Research Institute (2004).

yAccording to the same authors, the following compounds also induced resistance in cucumber against Colletotrichum lagenarium: galacturonic acid, gallic acid, glucuronic acid, glycine, hemimelletic acid, m-hydroxybenzoic acid, p-hydroxybenzoic acid, oxalic acid, phloroglucinol, protocatechuic acid, trimelletic acid, trimesic acid, and salicylic acid. 
Table 2. List of compounds claimed in the literature as abiotic disease resistance inducers in horticultural crops. ${ }^{\mathrm{z}}$

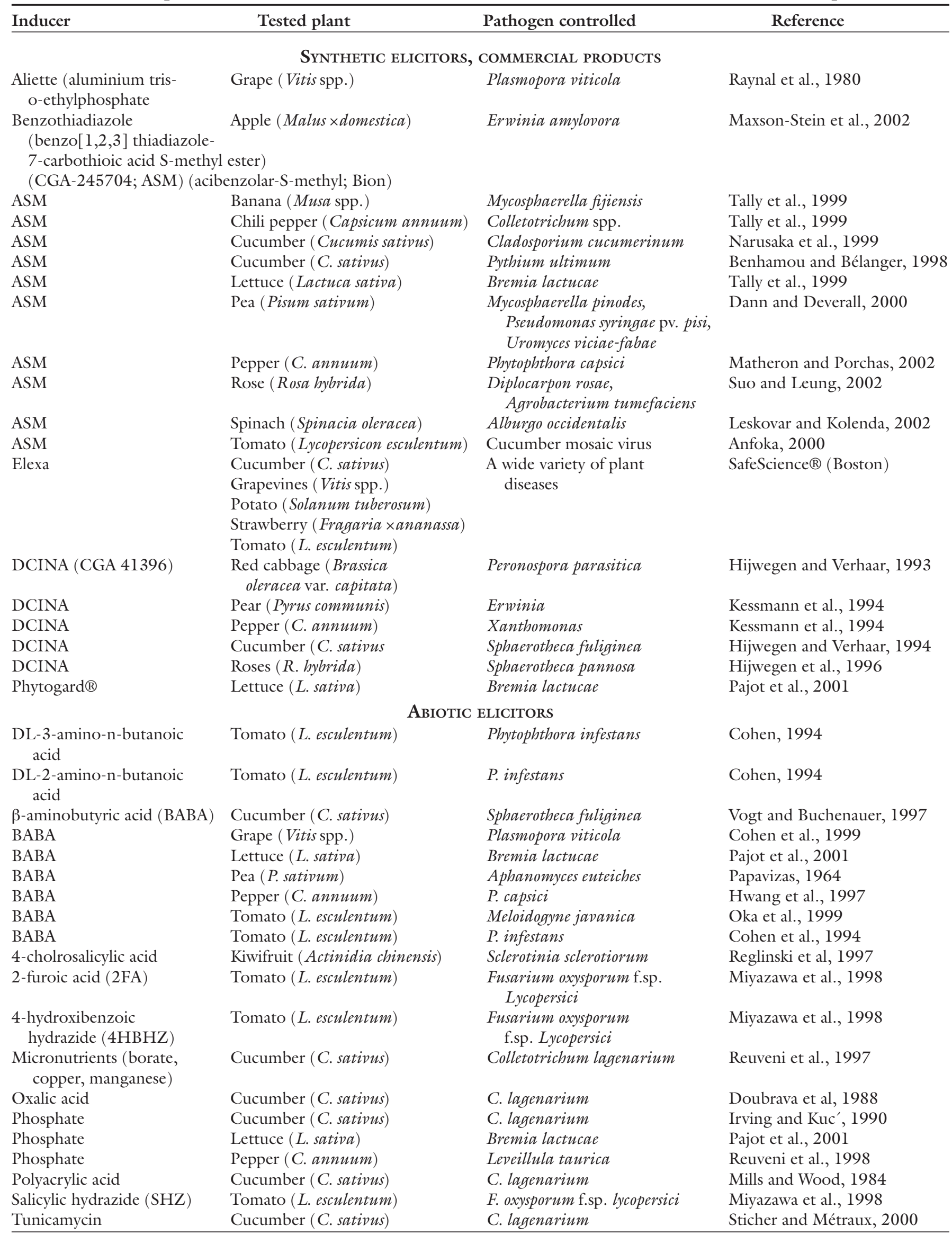

${ }^{2}$ This table was adapted from Scottish Crop Research Institute (2004). 
mildews (Bécot et al., 2000), and thus may control diseases caused by downy mildews via direct antifungal activity as well as through induced resistance.

The compound 2,6-dichloroisonicotinic acid (INA) and its methyl ester protects dicotyledonous and monocotyledonous plant species against a wide spectrum of pathogens (Uknes et al., 1992). Because INA has weak antifungal activity in vitro and induced the expression of SAR associated genes (e.g., the PR protein genes) prior to challenge inoculation, INA was among the first synthetic compounds that closely reproduced the SAR response. However, the commercial use of this compound is limited to expression of phytotoxicity in certain crops (Sticher et al., 1997).

Among the synthetic compounds, acibenzolar-S-methyl (ASM) is perhaps one of the most studied resistance inducer. Like INA, ASM shows practically no antifungal activity and leads to the expression of the same genes associated with SAR as SA (Ward et al., 1991). Weekly application of ASM to strawberry (Fragaria $\times$ ananassa) plants [0.25-2.0 mg. $\mathrm{mL}^{-1}(250-2000$ ppm) a.i.] resulted in a delay (about 2 d) in the development of grey mold ( $B$. cinerea) on harvested fruit that were being held at $5^{\circ} \mathrm{C}\left(41.0^{\circ} \mathrm{F}\right)$. Although the delay of disease onset was small, the authors stated that the delay increased storage life of the fruit by $15 \%$ to $20 \%$ (Terry and Joyce, 2000). Treatment of rose (Rosa hybrida) shoots with 50 $\mu \mathrm{M}$ ASM protected the shoots against the black spot pathogen, Diplocarpon rosae. The induction of resistance was associated with accumulation of the PR proteins PR-1, PR-2, PR-3, and PR-5 (Suo and Leung, 2002).

Another chemical disease resistance inducer that is effective in a number of horticultural crops is the non-protein amino acid, $\beta$-aminobutyric acid (BABA) (Cohen, 2002). Foliar application of BABA protected tomato and potato foliage against $P$. infestans (Cohen, 2002), broccoli (Brassica oleracea var. italica) against Alternariabrassicicola (Cohen, 2002), and lettuce against Bremia lactucae (Pajot et al., 2001). To further support its role as an inducer, BABA has no detectable antifungal activity in vitro or in planta. However, it appears to be unique among other inducers as it has been reported to have curative properties (Cohen, 1994). Cohen and Gisi (1994) showed that BABA altered cell wall structure of tomato plants, thereby making the tissues more resistant to degradation by pathogen produced cell wall degrading enzymes. Cohen et al. (1994) also demonstrated rapid and strong accumulation of PR proteins in tomato and tobacco after applying BABA as a leaf spray. Treatment with BABA protected pepper plants against Phytophthora capsici infection and reduced hyphal growth in and sporangial formation on BABA induced tissues (Lee et al., 2000). In further support for BABA as a resistance inducer, Lee et al. (2000) reported the formation of cell wall appositions that may restrict hyphal growth, in response to $P$. capsici infection. Degradation of mitochondria in hyphae of an incompatible $P$. capsici isolate in a resistant host and in a virulent isolate in a host plant with $\mathrm{BABA}$ induced resistance further suggests that BABA is inducing resistance.

\section{Postharvest disease resistance inducers}

Activation of defense responses and resistance in harvested crops has been demonstrated in various hostpathogen interactions through application of physical, chemical or biological inducers of resistance (Barkai-Golan, 2001; Terry and Joyce, 2004; Wilson et al., 1994). Thus, induced resistance may be a practical addition to postharvest disease management.

Although not dealing with harvested produce, Stermer and Hammerschmidt (1984) demonstrated that a brief heat shock induces resistance in cucumbers against Cladosporium cucumerinum. The resistance developed 15 to $21 \mathrm{~h}$ after heat shock treatment and was associated with stimulated ethylene production and changes in the plant cell wall (Stermer and Hammerschmidt, 1987). Heat treatment also induced resistance against powdery mildew in barley (Hordeum vulgare) seedlings (Schweizer et al., 1995). Thus, physical treatments, in this case heat, are effective means of inducing resistance that could be adapted to postharvest treatments of produce.

Heat treatment has been shown to affect the production of antifungal coumarins in citrus peel. For example, Kim et al. (2001) demonstrated that heat treatment of lemon (Citruslimon) fruit enhanced their ability to produce scoparone following infection with
Penicillium sp. The accumulation of the coumarin was significantly correlated with resistance. Several antifungal coumarins were also reported by BenYehoshua et al. (1992) to be induced by heat in citrus fruit peels, thus further supporting a role for heat treatment in inducing resistance.

Another physical treatment, ultraviolet light-C (UV-C), may also have a role as a resistance inducer. Treatment of seed with low doses of UV-C (wavelength of $290 \mathrm{~nm}$ or shorter) induced resistance in cabbage (Brassica oleracea var. capitata) to black rot (Xanthomonas campestris pv. campestris) in greenhouse production (Brown et al., 2001). UV-C also induced disease resistance in onion (Allium cepa) bulbs (Lu et al., 1987), carrot roots (Mercier et al., 1993), pepper fruit (Mercier et al., 2001), and tomato fruit (Liu et al., 1993). UV-induced resistance to $B$. cinerea and S. sclerotiorum in carrot root slices was associated with accumulation of the phytoalexin 6-methoxymellein (Mercier et al., 1993). However, high levels of 6-methoxymellein in carrots increases bitterness (Seljåsen et al., 2001). Thus, increasing 6-methoymellein as a means of inducing resistance may also reduce the quality of the produce by increasing bitterness.

The ability of antagonistic microorganisms to prevent postharvest diseases is generally related to their capacity to produce and secrete antibiotic substances or their ability to injure the pathogen directly (Barkai-Golan, $2001)$. However, microbial antagonistics have also been shown to induce resistance in host tissue. The antagonistic yeast-like fungus Aureobasidium pullulans was reported by Ippolito et al. (2000) to reduce decay caused by B. cinerea and Penicillium expansum in wounded apple (Malus $\times$ domestica) fruit. The inducer microorganism multiplied in the wounds and increased the activities of $\beta$-1,3-glucanase, chitinase and peroxidase in the treated wounds of the fruit. Thus, at least part of the control afforded by $A$. pullulans is through the induction of host defenses as well as through antagonism.

Recently, the effect of harpin protein, a bacterial protein known to induce resistance in foliage (e.g., Strobel et al., 1996), have been reported to induce resistance to fungal disease in apple fruit. De Capdeville et al. (2003) reported that harpin induced resistance 
to blue mold caused by $P$. expansum. Spraying the fruit a few days prior to harvest or direct treatment of fruit after harvest resulted in expression of resistance to $P$. expansum, thus illustrating the utility of this approach.

\section{Factors involved in practical use of induced resistance}

Although induced resistance is broad spectrum and many potential resistance inducer materials are available, several factors should be considered when designing control strategies using induced resistance. For example, many of the compounds that were described as resistance inducers were tested only in controlled conditions or in greenhouses. Although the information may be directly applicable to greenhouse production, plants growing under field conditions are exposed to a variety of biological and physical stresses that may impact a multitude of stress-related signaling pathways (Walling, 2000). Thus, careful field testing needs to be carried out to determine the efficacy of resistance inducers under normal production conditions. We previously discussed the involvement of two pathways in induced resistance signaling: one that is SA-dependent and another that is mediated by JA/ethylene. These different pathways play important roles in induced resistance against different pathogens (Ton et al., 2002). Thus, in order to induce resistance against different pathogens and even herbivores for practical disease and pest management, there may be the need for the activation of both pathways. Signaling pathways can interact either additively or antagonistically (Pieterse and van Loon, 1999; Walling, 2000). It has been demonstrated that there is synergistic effect of SAR and rhizobacteria-mediated ISR on the level of induced protection in arabidopsis against Pseudomonas syringae pv. tomato DC3000 (Van Wees et al., 2000). However, studies conducted on tomato demonstrated that chemical induction of SAR decreases the plant's ability to express wound-inducible proteinase inhibitors, one of the main components of induced resistance against herbivores that is mediated by JA (Heil and Bostock, 2002). Similarly, treating tomato leaves with ASM (an activator of SAR) increased their suitability for herbivorous caterpillars (Stout et al., 1999). SA-treatments, which also induce SAR, inhibit wound- and JA- induced responses in the same plant, and JA partially reduced the efficacy of chemical SAR elicitors (Thaler et al., 1999).

Another important factor to be considered in practical application of induced resistance is the fact that not all cultivars respond equally to induction by a certain activators. For example, we have found host genotypic variability in the ability of ASM to induce resistance to the hemibiotrophic pathogen Colletotrichum orbiculare in cucumber. In addition, when the same cultivars were induced with ASM and challenged with Didymella bryoniae, a necrotroph, some cultivars expressed resistance, but others showed little response and some became even more susceptible to this pathogen (A.B. da Rocha, L. Velasquez, and R. Hammerschmidt, unpublished). Genotypic variability in the ability to express ISR has also been found in arabidopsis. The PGPR strain WCS417r was used to screen the ability of 10 arabidopsis ecotypes to express ISR. Ecotypes RLD and Wassilewskija (Ws) were unable to express ISR, and this was associated with a reduced sensitivity to ethylene (Ton et al., 2001). Unfortunately few studies have included a wide range of cultivars in horticultural crops experiments involving induced resistance, and more information regarding possible differential responses will be valuable for practical use.

Even though induced resistance is thought to provide benefits for the defended plants through the reduction of disease, Kuc' (1995) suggested that induced resistance may impose metabolic costs to the plant. Considering that the plant defensive responses include metabolically active processes such as the hypersensitive response (Hammerschmidt and Nicholson, 1999), the production of molecules such as SA (Cameron, 2000), production of PR proteins (Van Loon, 1997) and production of phytoalexins and cell wall strengthening material (Hammerschmidt and Nicholson, 1999), this is not surprising. Kuc (1995) discussed whether stunted plants and lower productivity that appear after application of elicitors of phytoalexins accumulation may be caused by a marked diversion of energy and carbon precursors from other important processes.

The costs of induced resistance have been demonstrated by Heil (2001) who demonstrated that expres- sion defenses can, in the absence of pathogen or pest attack, reduce fitness. These costs can result from the allocation of the plant's resources to defense rather than to growth or reproduction. Because defense processes require energy and use carbon compounds that could otherwise be used for growth and development, it is not surprising that induced resistance may reduce growth or normal functions. However, this decrease in fitness is a good investment if it means that the plant can survive attack by a pathogen and successfully reproduce.

Applying JA to tomato led to a delay in fruit set, the formation of larger (but fewer) fruit, an increase in ripening time, and fewer seeds per fruit and per plant (Redman et al., 2001). According to the authors, the potentially desirable changes such as larger fruit size and lower seed number would not likely offset the associated delay in ripening and reduction in fruit number. The same kind of result was observed in onions, where induction of resistance against Alternaria porriwas significantly expressed in plants treated with methyl jasmonate (MeJa) at 10 $\mathrm{mM}$, but in l year marketable yield was not affected and in the second year of the same experiment, marketable yield was reduced (Arboleya et al., 2003). In this case, we may consider that reduction of disease by mechanisms activated during SAR and /or ISR may not be necessarily accompanied by increase in yield or better quality of horticultural crops.

Because induced resistance requires the induction of several biochemical changes in the plant, it is not surprising that there is a lag time between treatment and expression of resistance. In addition, most inducers do not have curative properties and must be applied prior to infection (Oostendorp et al., 2001). Thus, one approach to the practical use of the resistance inducers is to combine them with standard fungicides. The fungicides would provide protection for the plant while the induction process is taking place. There are also data suggesting that fungicide control can be enhanced by resistance inducers or activators. A synergistic effect between ASM and three different fungicides (metalaxyl, fosetyl-Al and $\mathrm{CuOH}$ ) was also demonstrated in the protection of arabidposis against Peronospora parasitica (Friedrich et al., 2001). 
Cohen (2002) reported that BABA is not effective in inducing resistance against powdery mildew. However, BABA enhanced the efficacy of triazole fungicides when the two were applied as a mixture. In a study with spinach, preventive applications of ASM plus the strobilurin fungicide trifloxistrobin at 7- to 10-d intervals appear to be an effective strategy to control white rust disease and improve leaf quality in this horticultural crop (Leskovar and Kolenda, 2002).

Because efficacy of the inducers may also depend on the part of the plant that was treated, the product delivery (i.e., how the inducers would be applied in order to optimize their action) is another factor to be considered. Attitalla et al. (2001) mentioned that in a growth chamber experiment, the application of a zoospore suspension of Phytophthora cryptogea to the roots of tomatoes resulted in root disease. However, when this inoculum was sprayed on the aerial parts of the tomato plants, it induced resistance to fusarium wilt. It was shown that seed treatment with fluorescent pseudomonads can induce resistance of tomato and hot pepper to disease caused by Pythium aphanidermatum (Ramamoorthy et al., 2002). The potential ability to easily use PGPR as a practical disease control has been demonstrated through experiments that have shown that soil application (Van Loon et al., 1998) and treatment of seed (Zehnder et al., 2001) are effective. Cohen (2002) reported that $\mathrm{BABA}$ induced resistance in tomato plants against nematodes by soil drench and by foliar spray. LatundeDada and Lucas (2001) showed that cowpea (Vigna unguiculata) seedlings raised from seeds treated with ASM were effectively induced for resistance against damping-off. These results suggest that ASM protects cowpea seedlings by priming the plant for an early defense response after infection rather than by altering the constitutive resistance of tissues. Thus, seed treatment with resistance inducers is potentially viable for field use.

Finally, the plant's response to the application of resistance inducers may be affected by the growth stage and development of these plants. For example, in a study with cauliflower plants, Phytogard induced resistance in young plants against downy mildew when sprayed at the concentration of $10 \mathrm{~mL}$ Phytogard diluted to $1 \mathrm{~L}(1.3$ $\mathrm{fl} \mathrm{oz} / \mathrm{gal})$. But it was also shown that the induced resistance was not systemic and lasted for only $15 \mathrm{~d}$. However, when Phytogard ${ }^{\circledR}$ was applied at the same concentration on roots of $30-\mathrm{d}$ old plants, the resistance was systemic (Bécot et al., 2000).

\section{Conclusions}

Much progress has been achieved in the study of induced resistance in horticultural crops in the last 15 years. Understanding the biochemical interactions occurring between plants, pathogens and the inducers will provide information that may be useful for the optimization of this new approach on disease control. The discovery of new compounds that are able to induce resistance is of great potential value in the integrated control of plant diseases, especially where resistance to fungicides or antibiotics is a problem. However, there are many questions about the use of resistance inducing agents, such as optimal timing and method of application for each crop, especially when they are integrated with other cultural practices. The differences in the efficacy of the inducers of resistance on different crop species and even cultivars are another challenge for their practical use in large scale horticultural production. Whether such differences are due to variations in uptake, perception, or dose response between species, or reflect genetic differences in the induction and regulation of plants defense pathways is still unclear.

As more information regarding induced resistance becomes available, new approaches to managing disease in horticultural crops may become available. These approaches includes integrating induced resistance with lower dosages of pesticides and the use of cultivars that better express resistance against a broad spectrum of diseases and insects.

\section{Literature cited}

Alström, S. 1991. Induction of disease resistance in common bean susceptible to halo blight bacterial pathogen after seed bacterization with rhizosphere Pseudomonads. J. Gen. Appl. Microbiol. 37:495-501.

Anfoka, G.H. 2000. Benzo-(1,2,3)thiadiazole-7-carbothioic acid S-methyl ester induces systemic resistance in tomato ( $L y$ copersicon esculentum Mill cv. Vollendung) to cucumber mosaic virus. Crop Protection 19:401-405.
Arboleya, J., A. da Rocha, I. Widders, B. Zandstra, and R. Hammerschmidt. 2003. Effect of chemical resistance activators on purple blotch disease, yield and quality of three onion cultivars. 4th Natl. Integrated Pest Mgt. Symp., Indianapolis. p. 35-36. (Abstr.)

Attitalla, I.H., P. Johnson, S. Brishammar, and P. Quintanilla. 2001. Systemic resistance to fusarium wilt in tomato induced by Phytophthora cryptogea. Phytopathologische Zeitschrift. 149:373-380.

Barkai-Golan, R. 2001. Postharvest diseases of fruit and vegetables. Development and control. Elsevier, London.

Bécot, S., E. Pajot, D. Le Corre, C. Monot, and D. Silué. 2000. Phytogard ${ }^{\circledR}\left(\mathrm{K}_{2} \mathrm{HPO}_{3}\right)$ induces localized resistance in cauliflower to downy mildew of crucifers. Crop Protection 19:417-425.

Benhamou, N. and G. Theriault. 1992. Treatment with chitosan enhances resistance of tomato plants to the crown and root rot pathogen Fusarium oxysporum f.sp. radicis-lycopersici. Physiol. Mol. Plant Pathol. 41:33-52.

Benhamou, N., P.J. Lafontaine, and M. Nicole. 1994. Induction of systemic resistance of fusarium crown and root rot in tomato plants by seed treatment with chitosan. Phytopathology 84:1432-1444.

Benhamou, N. and R. Bélanger. 1998. Induction of resistance to pythium dampingoffin cucumber plants by benzothiadiazole: Ultrastructure and cytochemistry of the host response. Plant J. 14:13-21.

Ben-Yehoshua, S., V. Rodov, J.J. Kim, and S. Carmeli. 1992. Preformed and induced antifungal materials of citrus fruit in relation to the enhancement of decay resistance by heat and ultraviolet treatments. J. Agr. Food Chem. 40:1217-1221.

Bostock, R.M., R.A. Laine, and J.A. Kuc'. 1982. Factors affecting the elicitation of sesquiterpenoid phytoalexin accumulation by eicosapentaenoic and arachidonic acid in potato. Plant Physiol. 70:1417-1424.

Brown, J.E., T.Y. Lu, C. Stevens, V.A. Khan, J.Y. Lu, C.L. Wilson, D.J. Collins, M.A. Wilson, E.C.K. Igwegbe, E. Chalutz, and S. Droby. 2001. The effect of low dose ultraviolet light-C seed treatment on induced resistance in cabbage to black rot (Xanthomonas campestris pv. campestris). Crop Protection 20:873-883.

Cameron, R.K. 2000. Salicylic acid and its role in plant defense responses: What do we really know? Physiol. Mol. Plant Pathol. 56:91-93.

Chester, K.S. 1933. The problem of acquired physiological immunity in plants. 
Quarterly Rev. Biol. 8:129-154 and 275-324.

Cohen, Y., U. Gisi, and E. Mösinger. 1991. Systemic resistance of potato plants against Phytophthora infestans induced by unsaturated fatty acids. Physiol. Mol. Plant Pathol. 38:255-263.

Cohen, Y., U. Gisi, and T. Niederman. 1993. Local and systemic protection against Phytophthora infestans induced in potato and tomato plants by jasmonic acid and jasmonic methyl-ester. Phytopathology 83:1054-1062.

Cohen, Y. 1994. Local and systemic control of Phytophthora infestans in tomato plants by DL-3-aminobutanoic acids. Phytopathology 84:55-59.

Cohen, Y. and U. Gisi. 1994. Systemic translocation of ${ }^{14} \mathrm{C}-\mathrm{DL}-3$-aminobutyric acid in tomato plants in relation to induced resistance against Phytophthora infestans. Physiol. Mol. Plant Pathol. 45:441-456.

Cohen, Y., T. Niderman, E. Mosinger, and R. Fluhr. 1994. $\beta$-Aminobutyric acid induces the accumulation of pathogenesisrelated proteins in tomato (Lycopersicon esculentum Mill.) and resistance to late blight infections caused by Phytophthora infestans. Plant Physiol. 104:59-66.

Cohen, Y., M. Reuveni, and A. Baider. 1999. Local and systemic activity of BABA (DL-3-aminobutyric acid) against Plasmopora viticola in grapevines. European J. Plant Pathol. 105:351-361.

Cohen, Y. R. 2002. $\beta$-Aminobutyric acidinduced resistance against plant pathogens. Plant Dis. 86:448-457.

Dann, E.K. and B.J. Deverall. 2000. Activation of systemic disease resistance in pea by an avirulent bacterium or a benzothiadiazole, but not by a fungal leaf spot pathogen. Plant Pathol. 49:324-332.

De Capdeville, G., S.V. Beer, C.B. Watkins, C.L. Wilson, L.O. Tedeschi, and J.R. Aist. 2003. Pre- and post-harvest harpin treatments of apples induce resistance to blue mold. Plant Dis. 87:39-44.

Doke, N., A.V. Ramirez, and K. Tomiayama. 1987. Systemic induction of resistance in potato plants against Phytophthora infestans by local treatment with hyphal wall components of the fungus. J. Phytopathol. 119:232-239.

Doubrava, N.S., R.A. Dean, and J. Kuc'. 1988. Induction of systemic resistance to anthracnose caused by Colletotrichum lagenarium in cucumber by oxalate and extracts from spinach and rhubarb leaves. Physiol. Mol. Plant Pathol. 33:69-79.

El Ghaouth,A., J. Arul, C. Wilson, and N. Benhamou. 1994. Ultrastructural and cy- tochemical aspects of the effect of chitosan on decay of bell pepper fruit. Physiol. Mol. Plant Pathol. 44:417-432.

Elliston, J.E., J. Kuc', and E.B. Williams. 1971. Induced resistance to bean anthracnose at a distance from the site of the inducing interaction. Phytopathology 61:1110-1112.

Fought, L. and J. Kuc'. 1996. Lack of specificity in plant extracts and chemicals as inducers of systemic acquired resistance in cucumber plants to anthracnose. J. Phytopathol. 144:1-6.

Friedrich, L., K. Lawton, R. Drietrich, M. Willits, R. Cade, and J. Ryals. 2001. NIMI overexpression in Arabidopsis potentiates plant disease resistance and results enhanced effectiveness of fungicides. Mol. Plant-Microbe Interaction 14:1114-1124.

Garrod, B., B.G. Lewis, M.J. Brittain, and W.P. Davies. 1982. Studies on the contribution of lignin and suberin to the impedance of wounded carrot root tissue to fungal invasion. New Phytologist 90:99-108.

Gottstein, H. and J. Kuc' . 1989. Induction of systemic resistance to anthracnose in cucumber by phosphates. Phytopathology 79:176-179.

Hammerschmidt, R., S. Acres, and J. Kuc'. 1976. Protection of cucumber against Colletotrichum lagenarium and Cladosporium cucumerinum. Phytopathology 66:790-793.

Hammerschmidt, R. and E.K. Dann. 1997. Induced resistance to disease, p.177-199. In: N.A. Rechcigl and J.E. Rechcigl (eds.). Environmentally safe approaches to plant disease control. CRC, Boca Raton, Fla.

Hammerschmidt, R. 1999. Induced disease resistance: How do induced plants stop pathogens? Physiol. Mol. Plant Pathol. 55:77-84.

Hammerschmidt, R. and R.L. Nicholson. 1999. A survey of defense responses to pathogens, p. 55-71. In: A.A. Agrawal, S. Tuzun, and E. Bent (eds.). Induced plant defenses against pathogens and herbivores: Biochemistry, ecology, and agriculture. APS Press, St. Paul, Minn.

Hammond-Kossack, K.E. and J.D.G. Jones. 1996. Resistance gene-dependent plant defense responses. Plant Cell 8:1773-1791.

Harding, V.K. and J.B. Heale. 1981. The accumulation of inhibitory compounds in the induced resistance response of carrot slices to Botrytiscinerea. Physiol. Mol. Plant Pathol. 18:7-15.

Heale, J.B. and S. Sharman. 1977. Induced resistance to Botrytis cinerea in root slices and tissue cultures of carrot (Daucus carota L.). Physiol. Mol. Plant Pathol. 10:51-61.

Heil, M. 2001. The ecological concept of costs of induced systemic resistance (ISR). European J. Plant Pathol. 107:137-146.

Heil, M. and R.M. Bostock. 2002. Induced systemic resistance (ISR) against pathogens in the context of induced plant defences. Ann. Bot. 89:503-512.

Herger, G., F. Klingauf, D. Mangold, E.H. Pommer, and M. Scherer. 1988. Efficacy of extracts of Reynoutria sachalinensis (F. Schmidt) Nakai (Pollygonaceae) against fungal diseases, especially powdery mildews. Nachrichtenblatt Deutschen Pflanzenschu. Brauns. 40:56-60.

Herger, G. and F. Klingauf. 1990. Control of powdery mildew fungi with extracts of the giant knotweed (Reynoutria sachalinensis). Mededelingen-Faculteit Landbouwwetenschappen Universiteit Gent 55:1007-1014.

Hijwegen, T. and M.A. Verhaar. 1993. Induced resistance to Peronospora parasitica in red cabbage. Neth. J. Plant Pathol. 99 (suppl. 3):103-107.

Hijwegen, T. and M.A. Verhaar. 1994. Effects of cucumber genotype on the induction of resistance to powdery mildew, Sphaerotheca fuliginea, by 2,6-dichloroisonicotinic acid. Plant Pathol. 44:756-762.

Hijwegen, T., M.A. Verhaar, and J.C. Zadoks. 1996. Resistance to Sphaerotheca pannosa in roses induced by 2,6 -dichloroisonicotinic acid. Plant Pathol. 45:631-635.

Hwang, B.K., J.Y. Sunwoo, Y.J. Kim, and B.S. Kim. 1997. Accumulation of $\beta$ 1,3 -glucanase and chitinase isoforms and salicylic acid in the DL- $\beta$-amino-n-butyric acid-induced resistance response of pepper stems to Phytophthora capsici. Physiol. Mol. Plant Pathol. 51:305-322.

Ippolito, A., A. El Gaouth, C.L. Wilson, and M. Wisniewski. 2000. Control of postharvest decay of apple fruit by Aureobasidium pullulans and induction of defense responses. Postharvest Biol. Technol. 19:265-272.

Irving, H.R. and J.A. Kuc'. 1990. Local and systemic induction of peroxidase, chitinase and resistance in cucumber plants by $\mathrm{K}_{2} \mathrm{HPO}_{4}$. Physiol. Mol. Plant Pathol. 37:355-366.

Jacobsen, B.J. and P.A. Backman. 1993. Biological and cultural plant disease controls: Alternatives and supplements to chemicals in IPM systems. Plant Dis. 77:311-315.

Jarvis, W.R. 1989. Fusarium crown and root rot of tomatoes. Phytoprotection 69:49-64. 
Jensen, B.D., A.O. Latunde-Dada, D. Hudson, and J.A. Lucas. 1998. Protection of Brassica seedlings against downy mildew and damping-off by seed treatment with CGA 245704, an activator of systemic acquired resistance. Pesticide Sci. 52:63-69.

Kachroo, P., K. Yoshioka, J. Shah, H.K. Dooner, and D.F. Klessig. 2000. Resistance to turnip crinkle virus in arabidopsis is regulated by two host genes and it is salicylic acid dependent but NPRl, ethylene and jasmonate independent. Plant Cell 12:677-690.

Kessmann, H., T. Staub, C. Hofmann, T. Maetzke, and J. Herzog. 1994. Induction of systemic acquired disease resistance in plants by chemicals. Annu. Rev. Phytopathol. 32:439-459.

Kim, Y.C., K.A. Blee, J. Robins, and A.J. Anderson. 2001. Oxycom ${ }^{\mathrm{TM}}$ under field and laboratory conditions increases resistance responses in plants. European J. Plant Pathol. 107:129-136.

Kuc', J. 1995. Phytoalexins, stress metabolism, and disease resistance in plants. Annu. Rev. Phytopathol. 33:275-297.

$\mathrm{Kuc}^{\prime}$, J. 1982. Induced immunity to plant disease. Bioscience 32:854-860.

Latunde-Dada, A.O. and J.A. Lucas. 2001. The plant defense activator acibenzolar-Smethyl primes cowpea [ Vigna unguiculata (L.) Walp.] seedlings for rapid induction of resistance. Physiol. Mol. Plant Pathol. 58:199-208.

Lee, Y.K., J.K. Hong, S. Hippe-Sanwald, and B.K. Hwang. 2000. Histological and ultrastructural comparisons of compatible, incompatible and DL- $\beta$-amino-n-butyric acid-induced resistance responses of pepper stems to Phytophthora capsici. Physiol. Mol. Plant Pathol. 57:269-280.

Leskovar D.I. and K. Kolenda. 2002. Strobilurin + acibenzolar-S-methyl controls white rust without inducing leaf chlorosis in spinach. Ann. Appl. Biol. 140:171-175.

Liu, J., C. Stevens, V.A. Khan, J.Y. Lu, C.L. Wilson, O. Adeyeye, M.K. Kabwe, P.L. Pusey, E. Chalutz, T. Sultana, and S. Droby. 1993. Application of ultraviolet-C light on storage rots and ripening of tomatoes. J. Food Protection 56:868-872.

Liu, L., J.W. Kloepper, and S. Tuzun. 1995a. Induction of systemic acquired resistance in cucumber by plant growthpromoting bacteria: Duration of protection and effect of host resistance on protection and root colonization. Phytopathology 85:1064-1068.

Liu, L., W. Kloeper, and S. Tuzun. 1995b. Induction of systemic resistance in cucum- ber against Fusarium wilt by plant growthpromoting rhizobacteria. Phytopathology 85:695-698.

Lu, J.Y., C. Stevens, P. Yakubu, and P.A. Loretan. 1987. Gamma electron beam, and UV radiation on control of storage rots and quality of Walla Walla onions. J. Food Processing Preservation 12:53-62.

Lyon, G.D., T. Reglinski, R.S. Forrest, and A.C. Newton. 1995. The use of resistance elicitors to control plant diseases. Aspects Appl. Biol. 42:227-234.

Madamanchi, N.R. and J. Kuc'. 1991. Induced systemic resistance in plants, $\mathrm{p}$. 347-362. In: G.T. Cole and H.C. Hoch (eds.). The fungal spore and disease initiation in plants and animals. Plenum, New York.

Matheron, M.E. and M. Porchas. 2002. Suppression of phytophthora root and crown rot on pepper plants treated with acibenzolar-S-methyl. Plant Dis. 86:292-297.

Maxson-Stein, K., S.Y. He, R. Hammerschmidt, and A.L. Jones. 2002. Effect of treating apple with acibenzolar-S-methyl on fire blight expression of pathogenesis-related protein genes. Plant Dis. 86:785-790.

Mercier, J., J. Arul, R. Ponnanapalan, and M. Boulet. 1993. Induction of 6methoxymellein and resistance to storage pathogens in carrot slices by UV-C. J. Phytopathol. 137:44-54.

Mercier, J., M. Baka, B. Reddy, R. Corcuff, and J. Arul. 2001. Shortwave ultraviolet irradiation for control of decay caused by Botrytis cinerea in bell pepper: Induced resistance and germicidal effects. J. Amer. Soc. Hort. Sci. 126:128-133.

Métraux, J.P., C. Nawrath, and T. Genoud. 2002. Systemic acquired resistance. Euphytica 124:237-243.

Mills, P.R. and R.K.S. Wood. 1984. The effects of polyacrylic acid, acetylsalicylic acid and salicylic acid on resistance of cucumber to Colletotrichum lagenarium. Phytopathologische Zeitschrift. 111:209-216.

Miyazawa, J., T. Kawabata, and N. Ogasawara. 1998. Induction of an acidic isozyme of peroxidase and acquired resistance to wilt disease in response to treatment of tomato roots with 2 -furoic acid, 4-hydroxybenzoic hydrazide or salicylic hydrazide. Physiol. Mol. Plant Pathol. 52:115-126.

Narusaka, Y., M. Narusaka, T. Horio, and H. Ishii. 1999. Comparison of local and systemic induction of acquired disease resistance in cucumber plants treated with benzothiadiazoles or salicylic acid. Plant Cell Physiol. 40:388-395.
Oka, Y., H. Koltai, M. Bar-Eyal, M. Mor, E. Sharon, I. Chet, and Y. Spiegel. 2000. New strategies for the control of plant-parasitic nematodes. Pest Mgt. Sci. 56:983-988.

Oka, Y., Y. Cohen, and Y. Spiegel. 1999. Local and systemic induced resistance to the root-knot nematode Meloidogyne javanica in tomato by DL- $\beta$-aminobutyric acid. Phytopathology 89:1138-1143.

Oostendorp, M., W. Kunz, B. Dietrich, and T. Staub. 2001 . Induced disease resistance in plants by chemicals. European J. Plant Pathol. 107:19-28.

Pajot, E., D. Le Corre, and D. Silué. 2001. Phytogard $^{\circledR}$ and DL- $\beta$-amino butyric acid (BABA) induce resistance to downy mildew (Bremia lactucae) in lettuce (Lactuca sativa L.). European J. Plant Pathol. 107:861-869.

Papavizas, G.C. 1964. Greenhouse control of Aphanomyces root rot of peas with aminobutyric acid and methylaspartic acid. Plant Dis. Rptr. 48:537-541.

Pharand, B., O. Carisse, and N. Benhamou. 2002. Cytological aspects of compost-mediated induced resistance against fusarium crown and root rot in tomato. Phytopathology 92:424-438.

Pieterse, C.M.J., S.C.M. van Wees, E. Hoffland, J.A. van Pelt, and L.C. van Loon. 1996. Systemic resistance in arabidopsis induced by biocontrol bacteria is independent of salicylic acid accumulation and pathogenesis-related gene expression. Plant Cell 8:1225-1237.

Pieterse, C.M.J., S.C.M. van Wees, J.A. van Pelt, M. Knoester, R. Laan, H. Gerrits, P. J. Weisbeek, and L.C. van Loon. 1998. A novel signaling pathway controlling induced systemic resistance in arabidopsis. Plant Cell 10:1571-1580.

Pieterse, C.M.J. and L.C. van Loon. 1999. Salicylic acid-independent plant defense pathways. Trends Plant Sci. 4:52-58.

Ramamoorthy, V., T. Raguchander, and S. Samiyappan. 2002. Enhancing resistance of tomato and hot pepper to Pythium diseases by seed treatment with fluorescent pseudomonads. European J. Plant Pathol. 108:429-441.

Raynal, G., A. Ravise, and G. Bompeix. 1980. Action of aluminium tris-o-ethylphosphonate on Plasmopora viticola pathogenicity and on stimulation of defense reaction of grapevine. Ann. Phytopathol. $12: 163-175$.

Redman, A., D.F. Cipollini Jr., and J.C. Schultz. 2001. Fitness costs of jasmonic acid-induced defense in tomato, Lycopersicon esculentum. Oecologia 126:380-385. 
Reglinski, T., G.D. Lyon, and A.C. Newton. 1995. The control of Botrytis cinerea and Rbizoctonia solani on lettuce using elicitors extracted from yeast cell walls. J. Plant Dis. Protection 102:257-266.

Reglinski, T., P.R. Poole, G. Whitaker, and S.M. Hoyte. 1997. Induced resistance against Sclerotinia sclerotiorum in kiwi fruit leaves. Plant Pathol. 46:716-721.

Reglinski, T., G. Whitaker, J.M. Cooney, J.T. Taylor, P.R. Poole, P.B. Roberts, and K.K. Kim. 2001. Systemic acquired resistance to Sclerotinia sclerotiorum in kiwifruit vines. Physiol. Mol. Plant Pathol. 58:111-118.

Reuveni, M., V. Agapov, and R. Reuveni. 1997. A foliar spray of micronutrient solutions induces local and systemic protection against powdery mildew (Sphaerotheca fuliginea) in cucumber plants. European J. Plant Pathol. 103:581-588.

Reuveni, R., G. Dor, and M. Reuveni. 1998. Local and systemic control of powdery mildew (Leveillula taurica) on pepper plants by foliar spray of monopotassium phosphate. Crop Protection 17:703-709.

Reuveni R., G. Dor, M. Raviv, M. Reuveni, and S. Tuzun. 2000. Systemic resistance against Sphaerotheca fuliginea in cucumber plants exposed to phosphate in hydroponics system and its control by foliar spray of mono-potassium phosphate. Crop Protection 19:355-361.

Ricker, K.E. and R.M. Bostock. 1992. Evidence for release of the arachidonic acid and its metabolites from sporangia of Phytophthora infestans during infection of potato. Physiol. Mol. Plant Pathol. 41:61-72.

Ross, A.F. 1961. Systemic acquired resistance induced by localized virus infection in plants. Virology 14:340-358.

Ryals, J., K. Weymann, K. Lawton, L. Friedrich, D. Ellis, H.Y. Steiner, J. Johnson, T. Delaney, J. Taco, P. Vos, and S. Uknes. 1997. The arabidopsis NIMl protein shows homology to the mammalian transcription factor inhibitor IkB. Plant Cell 9:425-439.

Schmidt, A., S. Eisemann, S. Strathmann, K.A. Emslie, and B. Seddon. 1996. Mode of action of extracts from giant knotweed (Reynoutria sachalinensis) on Botrytis cinerea, causal organism of grey mould. Federal Biol. Inst. 32:421.

Schweizer, P., L. Vallelian-Bindschedler, and E. Mosinger. 1995. Heat-induced resistance in barley to the powdery mildew fungus Erysiphe graminis f.sp. hordei. Physiol. Mol. Plant Pathol. 47:51-66.

Scottish Crop Research Institute. 2004. Compounds that stimulate plant resistance to infection when applied exogenously. 19 Nov. 2004. <http://www.drastic.org. $\mathrm{uk} />$.

Seljåsen, R., H. Hoftun, and G.B. Bengtsson. 2001. Sensory quality of ethyleneexposed carrots (Daucus carota L., cv. 'Yukon') related to the contents of 6-methoxymellein, terpenes and sugars. J. Sci. Food Agr. 81:54-61.

Stermer B.A. and R. Hammerschmidt. 1984. Heat shock induces resistance to Cladosporium cucumerinum and enhances peroxidase activity in cucumbers. Physiol. Mol. Plant Pathol. 25:239-249.

Stermer, B.A. and R. Hammerschmidt. 1987. Association of heat shock induced resistance to disease with increased accumulation of insoluble extension and ethylene synthesis. Physiol. Mol. Plant Pathol. 31:453-461.

Sticher, L., B. Mauch-Mani, and J.P. Métraux. 1997. Systemic acquired resistance. Ann. Rev. Phytopathol. 35:235-270.

Sticher, L. and J.P. Métraux. 2000. Inhibitors of $\mathrm{N}$-linked glycosylation induce systemic acquired resistance in cucumber. Physiol. Mol. Plant Pathol. 56:245-252.

Stout, M.J.,A.L. Fidantsef, S.S. Duffey, and R.M. Bostock. 1999. Signal interactions in pathogen and insect attack: Systemic plantmediated interactions between pathogens and herbivores of the tomato, Lycopersicon esculentum. Physiol. Mol. Plant Pathol. 54:115-130.

Strobel, N.R, C. Ji, S. Gopalan, J.A. Kuc', and S.Y. He. 1996. Induction of systemic acquired resistance in cucumber by Pseudomonas syringae pv syringae $61 \mathrm{HrpZ}(\mathrm{Pss})$ protein. Plant J. 9:431-439.

Suo, Y. and W.M. Leung. 2002. Induction of resistance to Diplocarpon rosae and Agrobacterium tumefaciens by acibenzolar-S-methyl $(\mathrm{BTH})$ in rose. Zeitschrift fur Pflanzenkrankheiten Pflazenschutz 108:382-391.

Tally, A., M. Oostendorp, K. Lawton, T. Staub, and B. Bassi. 1999. Commercial development of elicitors of induced resistance to pathogens, p. 357-369. In: A.A. Agrawal, S. Tuzun, and E. Bent (eds.). Induced plant defense against pathogens and herbivores: Biochemistry, ecology and agriculture. APS Press, St. Paul, Minn.

Terry, L.A. and D. C. Joyce. 2000. Suppression of grey mould on strawberry fruit with the chemical plant activator acibenzolar. Pest Mgt. Sci. 56:989-992.

Terry L.A. and D.C. Joyce. 2004. Elicitors of induced disease resistance in postharvest horticultural crops: A brief review. Postharvest Biol. Technol. 32:1-13
Thaler, J.S., A.L. Fidantsef, S.S. Duffey, and R.M. Bostock. 1999. Trade-offs in plant defense against pathogens and herbivores: A field demonstration of chemical elicitors of induced resistance. J. Chem. Ecol. 25:1597-1609.

Ton, J., S. Davison, L.C. Van Loon, and C.M.J. Pieterse. 2001. Heritability of rhizobacteria-mediated induced systemic resistance and basal resistance in arabidopsis. European J. Plant Pathol. 107:63-68.

Ton, J., J.A. Van Pelt, L.C. Van Loon, and C.M. Pieterse. 2002. Differential effectiveness of salicylate-dependent and jasmonate/ethylene-dependent induced resistance in Arabidopsis. Mol. Plant-Microbe Interaction 15:27-34.

Uknes, S., B. Mauch-Mani, M. Moyer, S. Potte, S. Williams, S. Dincher, D. Chandler, A. Slusarenko, E. Ward, and J. Ryals. 1992. Acquired resistance in arabidopsis. Plant Cell 4:645-656.

Van Loon, L.C. 1997. Induced resistance in plants and the role of pathogenesis-related proteins. European J. Plant Pathol. 103:753-756.

Van Loon, L.C., P.A.H.M. Bakker, and C.M.J. Pieterse. 1998. Systemic resistance induced by rhizosphere bacteria. Annu. Rev. Phytopathol. 36:453-483.

Van Peer, R., G.J. Niemann, and B. Schippers. 1991. Induced resistance and phytoalexin accumulation in biological control of fusarium wilt of carnation by Pseudomonas sp. strain WCS417r. Phytopathology 81:728-734.

Van Peer, R. and B. Schippers. 1992. Lipopolysaccharides of plant growth promoting Pseudomonas spp. Strain WCS417r induce resistance in carnation to fusarium wilt. Neth. J. Plant Pathol. 98:129-139.

Van Wees, S.C.M., C.M.J. Pieterse, A. Trijssenaar, Y.A. Van't Westende, F. Hartog, and L.C. Van Loon. 1997. Differential induction of systemic resistance in Arabidopsis by biocontrol bacteria. Mol. Plant-Microbe Interaction 10:716-724.

Van Wees, S.C.M., E.A.M. De Swart, J.A. Van Pelt, L.C. Van Loon, and C.M.J. Pieterse. 2000. Enhancement of induced resistance by simultaneous activation of salicylate- and jasmonate- dependent defense pathways in Arabidopsis thaliana. Proc. Natl. Acad. Sci. U.S.A. 97:8711-8716.

Vogt, W. and H. Buchenauer. 1997. Enhancement of biological control by combination of antagonistic fluorescent Pseudomonas strains and resistance inducers against damping off and powdery mildew in cucumber. J. Plant Dis. Plant Protection 104:272-280. 
Walling, L.L. 2000. The myriad plant responses to herbivores. J. Plant Growth Regulat. 19:195-216.

Ward, E.R., S.J. Uknes, S.C. Williams, S.S. Dincher, D.L. Wiederhold, D.C. Alexander, P. Ahl-Goy, J.P. Metraux, and J.A. Ryals. 1991. Coordinate gene activity in response to agents that induce systemic acquired resistance. Plant Cell 3:1085-1094.

Washington, W.S., N. Shanmuganathan, and C. Forbes. 1992. Fungicide control of strawberry fruit rots, and field occurrence of resistance of Botrytis cinerea to iprodione, benomyl and dichlofluanid. Crop Protection 11:355-360.

Wilson, C.L., A. El ghaouth, E. Chalutz, S. Droby, C. Stevens, J.Y. Lu, V. Khan, and J. Arul. 1994. Potential of induced resistance to control postharvest diseases of fruit and vegetables. Plant Dis. 78:837-844.

Zehnder, G.W., J.F. Murphy, E.J. Sikora, J.W. Kloepper. 2001. Application to rhizobacteria for induced resistance. European J. Plant Pathol. 107:39-50. 